\title{
Herbal medicine used to treat primary infertility in women by traditional practioners of Vijayapur (Bijapur) district of Karnataka, India
}

\author{
Arati Laddimath, Srinath Rao* \\ Plant tissue culture and genetic Engineering Laboratory, \\ Department of post Graduate studies and Research in Botany, \\ Gulbarga University, Kalaburagi 585106, Karnataka, India. \\ *Corresponding author e-mail: srinathraomm@gmail.com
}

\begin{abstract}
Keywords: Traditional herbal medicine, traditional practitioners, primary infertility, Vijayapur, Karnataka, India

ABSTRACT. An ethno-botanical survey of Vijayapur district comprising five tehsils was conducted during February 2014 to December 2015. The main purpose of this survey was to document the traditional use of medicinal plants for primary infertility in women in vijayapur district. 13 species belonging to 13 genera and 12 families were found to be used to treat primary infertility. The scientific name, family, local name, habit along with part used and mode of their administration are provided.
\end{abstract}

\section{INTRODUCTION}

India is a major centre of origin and diversity of medicinal plants. Traditional knowledge of herbal remedy to treat human diseases is fast declining in many parts of the world, including India. In India, about 2500 species belonging to more than 1000 genera and about 158 families are used in indigenous system of medicine(Tewari,1999).Traditional practitioners have their own traditional knowledge to treat primary infertility. "Primary infertility refers to who have not become pregnant after at least 1 year having sex without using birth control methods". Due to restless work, stress, strain and late marriage and chemical constituent food a lot of women facing problem of primary infertility. Most of the women do not approach doctors due to costly medicine, and different instrumental treatments like Laparoscopy test, Enzyme test, X-ray test, etc. Herbal medicines are cheap and easily available. The present study was initiated with an aim to identify medicinal plants resources from traditional practitioners of Vijayapur district to treat primary infertility

\section{STUDY AREA}

The Vijayapur district of Karnataka state is located between north latitude $16^{\circ} .01^{\prime}, 17^{\circ} .45^{\prime}$, and east longitude $75^{\circ} .03^{\prime}, 76^{\circ} .29^{\prime}$. The district has its border with Belgaum, Bagalkot, Raichur, Gulbarga district and to north, Sholapur district of Maharashtra state.

Vijyapur district is plain Deccan plateau, which is from 365-610 met height above sea level. This region is slope towards west to east. The river Doni , Krishna, Bheema, and their tributaries are flows according to the slope.

The total area of Vijayapur district is $10,541 \mathrm{sq} \mathrm{kms}$. There are five talukas of Vijayapur district i,e., Vijayapur, Muddebihaal, Sindagi, Basavanbagevaadi and Indi. Bordered by the Bheema River in the north and the River Krishna in the south.

The district consists of the dry and arid tract of the Deccan Plateau. The temperature varies between $42^{\circ} \mathrm{c}$ during summer and $15^{\circ} \mathrm{c}$ during winter season respectively. In May mean maximum temperature is $40^{\circ} \mathrm{c}$. The climate of this region is arid, tropical and steppe type.

The soil of Vijayapur district area is rich in content of basalt rock, magnetite, magnesium, aluminium and iron oxide.

The Vijayapur district receives normal rainfall $578.0 \mathrm{~mm}$ and the vegetation of this region is mainly dry and deciduous and broadly as vegetation on plains. The natural vegetation near Alamatti 
Dam area is like dry and hot having rich flora. Many local traditional practitioners collect the plants from this area to cure the diseases

\section{MATERIAL AND METHODS}

Ethno botanical survey during February 2014 to December 2015 carried out in Vijayapur district. For this, frequent field trips were made to 15 selected villages belonging to all 5 tehsils of the districts. 17 herbal healers (16 male and 1 women) of age group 48 to 84 years, herbal healers were interviewed, data and information recorded in the standard questionnaire. Collected data and information include, Vernacular name of traditionally used medicinal plants, part used, method of preparation and dosage. Medicinal plant species were photographed in the field. Plant specimens were identified consulting with experts, by referring Flora of Gulbarga District (Seetharam et.al., 2000), Three volumes of the Flora of presidency of Madras (Gamble, 1957). The voucher specimens were stored at the herbarium centre, Department of Post graduate studies and Research in Botany, Gulbarga University, Kalaburagi.

\section{RESULT AND DISCUSSION}

In the present account, 13 species of angiosperms belonging to 13 genera and 12 families are reported (Table 1). The predominant family is solanaceae with 2 species. Herbal preparation for primary infertility was in the form of decoction, juices, pastes etc. Other substances like honey, cow milk, safflower oil and cow ghee are also used in various preparation. All plant species are arranged in alphabetic order, for each species scientific name, Family, vernacular name, habit, part used and mode administrated are provided. Different plant parts were used to treat primary infertility among these leaves $(28.5 \%)$, root $(28.5 \%)$, fruit $(7.14 \%)$, flower bud $(7.14 \%)$, bark $(7.14 \%)$, and whole plant $(7.14 \%)$, in descending order. Most of the work has been done on medicinal plants of various districts of Karnataka state but no information is available on plants used for primary infertility in Vijayapur district. Review of related literature reveals that medicinal plants used by the traditional practitioners of this area are not recommended on other areas for same purpose (Trirathi et.al., 2010), (Rajash et.al 2008). However these plants were used for other human ailments. For instance leaves of Tribulus terrestris L. Used for expel stones (Ghatapanadi et.al., 2010). Leaves of Tridax procumbence used for haemorrhage, Leaves of Albizia lebbeck used for snake bite and Leaves of Eagle mermolus L. used to expel kidney stones in Andra Pradesh (Madhu and Ravindra Naik, 2009). Leaves and twigs of Caesalpinia bonducella are traditionally used for the treatment of tumors, inflammation and liver disorder, toothache, elephantiasis and smallpox. (Khan et.al., 2012).

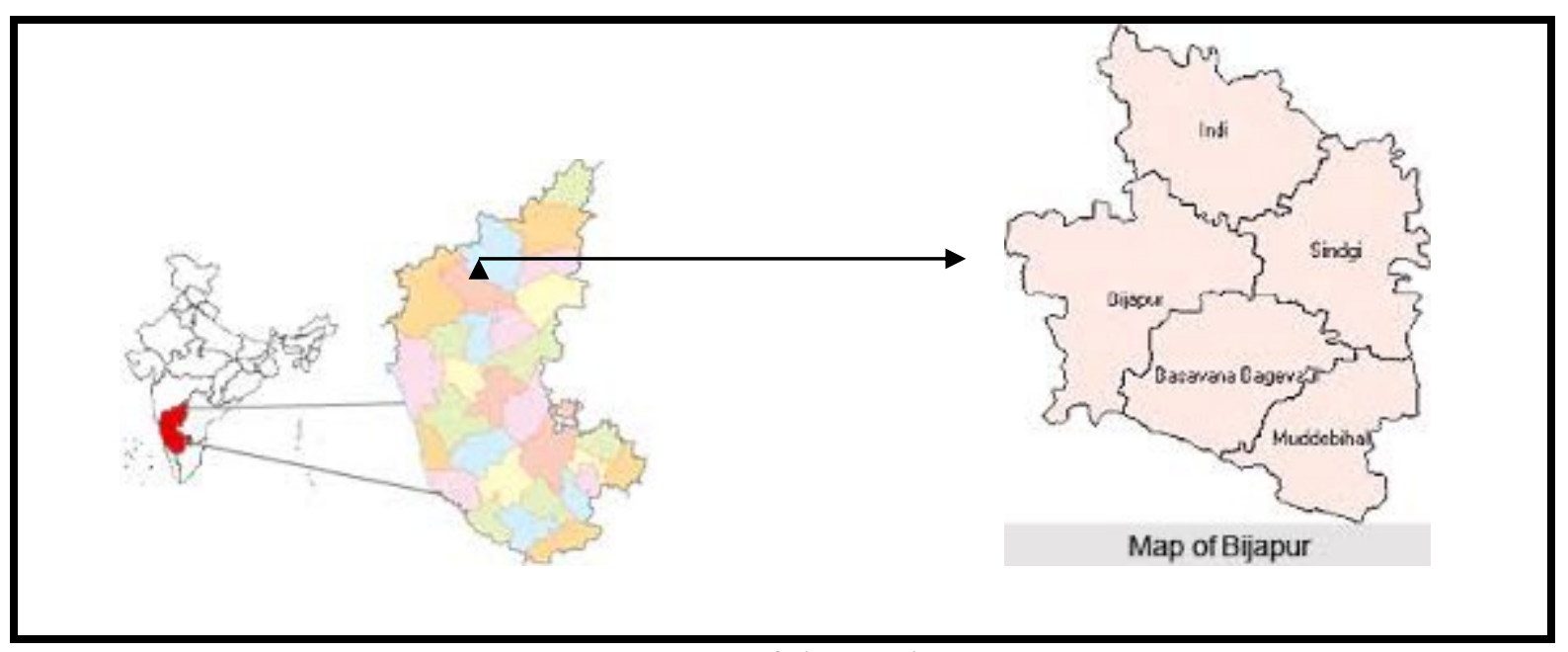

Fig.1: Map of the study area 
Table 1: Medicinal plants used to treat primary infertility in women by traditional practioners of Vijayapur (Bijapur) district

\begin{tabular}{|c|c|c|c|c|c|}
\hline Plant name & Family & $\begin{array}{l}\text { Local/Vern } \\
\text { Name }\end{array}$ & Habit & $\begin{array}{l}\text { Part } \\
\text { used }\end{array}$ & Mode of administration \\
\hline $\begin{array}{l}\text { Aegle } \\
\text { marmelos(L.). }\end{array}$ & Rutaceae & Bilva patre & Tree & Fruit & $\begin{array}{l}\text { Endocarp of the fruit, make it } \\
\text { into tablet and administered } \\
\text { to eat at morning with empty } \\
\text { stomach for two month }\end{array}$ \\
\hline $\begin{array}{l}\text { Albizia lebbeck } \\
\text { (L.) Willd. }\end{array}$ & Mimoceae & Gulmoher & Tree & $\begin{array}{l}\text { Bark } \\
\& \\
\text { leaves }\end{array}$ & $\begin{array}{l}200 \text { gm bark and } 100 \mathrm{gm} \text { of } \\
\text { young leaves are ground and } \\
\text { boiled in } 1000 \mathrm{ml} \text { of water } \\
\text { till it becomes } 500 \mathrm{ml} \text {. } \\
\text { Filtrate decoction is given } \\
\text { with honey for } 25 \text { days with } \\
\text { empty stomach at morning }\end{array}$ \\
\hline $\begin{array}{l}\text { Amaranthus } \\
\text { gangeticus L. }\end{array}$ & Amaranthaceae & kirasaalige & Herb & Root & $\begin{array}{l}\text { Root is rubbed with rice soup } \\
\text { and administered to drink } \\
\text { morning during the } \\
\text { menstrual cycle }\end{array}$ \\
\hline $\begin{array}{l}\text { Argemone } \\
\text { maxicana } \mathrm{L} .\end{array}$ & Papaveraceae & Golagolike & Herb & $\begin{array}{l}\text { Whole } \\
\text { plant }\end{array}$ & $\begin{array}{l}\text { Collect whole plant at } \\
\text { morning. ground and } \\
\text { administered to drink five } \\
\text { gm, after four days of } \\
\text { Menses }\end{array}$ \\
\hline $\begin{array}{l}\text { Barleria } \\
\text { prionitis L. }\end{array}$ & Acathaceae & Mulajaji & Herb & Root & $\begin{array}{l}\text { Root is rubbed with cow } \\
\text { ghee and administered to eat } \\
\text { during the menstrual cycle }\end{array}$ \\
\hline $\begin{array}{l}\text { Caesalpinia } \\
\text { bunducella Roxb }\end{array}$ & Caesalpinaceae & Gajaga & Tree & Leaves & $\begin{array}{l}50 \text { gm of leaves ground and } \\
\text { administered to drink with } 10 \\
\text { gm sesame oil once in a day } \\
\text { for } 7 \text { days from the first day } \\
\text { of Menses }\end{array}$ \\
\hline $\begin{array}{l}\text { Cucumis } \\
\text { prophetarum }\end{array}$ & Cucurbitaceae & $\begin{array}{l}\text { Mullu } \\
\text { mekkekayi }\end{array}$ & Climber & Fruit & $\begin{array}{l}\text { The fruit is cut into half } \\
\text { equal part, rubbed with goat } \\
\text { milk. The fluid is applied to } \\
\text { vagina as ointment. }\end{array}$ \\
\hline $\begin{array}{l}\text { Hibiscus rosa- } \\
\text { sinensis L. }\end{array}$ & Malvaceae & Daasavaal & shrub & Root & $\begin{array}{l}\text { Root is rubbed with milk of } \\
\text { white cow, administered to } \\
\text { take during the menstrual } \\
\text { cycle }\end{array}$ \\
\hline $\begin{array}{l}\text { Musa } \\
\text { paradisiaca L. }\end{array}$ & Musaceae & Baale gida & Shrub & $\begin{array}{l}\text { flower } \\
\text { buds }\end{array}$ & $\begin{array}{l}50 \text { to } 60 \mathrm{gm} \text { flower buds } \\
\text { ground. } 20 \mathrm{ml} \text { of sesame oil } \\
\text { mixed with juice and } \\
\text { administered to drink seven } \\
\text { days }\end{array}$ \\
\hline $\begin{array}{l}\text { Solanum } \\
\text { melongena L. }\end{array}$ & solanaceae & Baal badane & Herb & fruit & $\begin{array}{l}\text { Unripe fruit rolled in } \\
\text { powdered sugar and which is } \\
\text { kept in vulva up to } 4-5 \text { hours } \\
\text { at night }\end{array}$ \\
\hline
\end{tabular}




\begin{tabular}{|l|l|l|l|l|l|}
\hline $\begin{array}{l}\text { Tribulus } \\
\text { terrestris L. }\end{array}$ & Zygophyllaceae & $\begin{array}{l}\text { Neggina } \\
\text { mullu }\end{array}$ & Creeper & leaves & $\begin{array}{l}100 \text { gm of Leaves ground } \\
\text { with } 100 \text { ml of water and } \\
\text { filter. The filtrate is } \\
\text { administered to drink at } \\
\text { morning for 10-15 days }\end{array}$ \\
\hline $\begin{array}{l}\text { Tridax } \\
\text { procumbens L. }\end{array}$ & Compositeae & Tikki kasa & Herb & leaves & $\begin{array}{l}100 \text { gm of Leaves ground } \\
\text { with 100 ml of water and } \\
\text { filtered. The filtrate juice is } \\
\text { administered to drink at } \\
\text { morning for 15-20 days }\end{array}$ \\
\hline $\begin{array}{l}\text { Withania } \\
\text { somnifera } \\
\text { (L.)Dunal. }\end{array}$ & solanaceae & $\begin{array}{l}\text { Ashwa } \\
\text { gandha }\end{array}$ & shrub & Root & $\begin{array}{l}\text { Roots are powdered, } \\
\text { administered to drink one } \\
\text { spoonful powder with } \\
\text { buffalo milk for seven days } \\
\text { from first day of menses with } \\
\text { empty stomach. }\end{array}$ \\
\hline $\begin{array}{l}\text { Zizipus jujuba } \\
\text { Lam.,non Mill. }\end{array}$ & Rhamnaceae & Baarikaayi & Shrub & Leaves & $\begin{array}{l}10 \text { gms of young leaves } \\
\text { ground, taken with 10 ml of } \\
\text { curd. }\end{array}$ \\
\hline
\end{tabular}

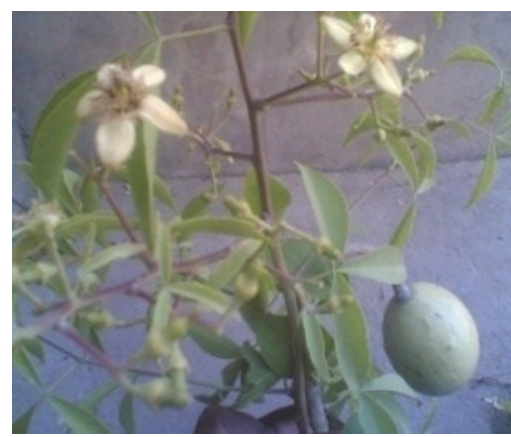

Aegle marmelos

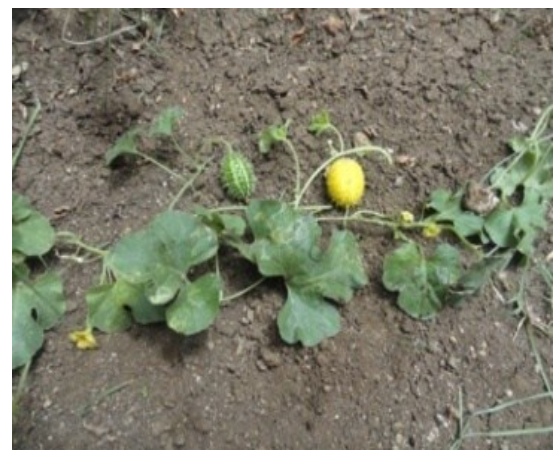

Cucumis prophetarum

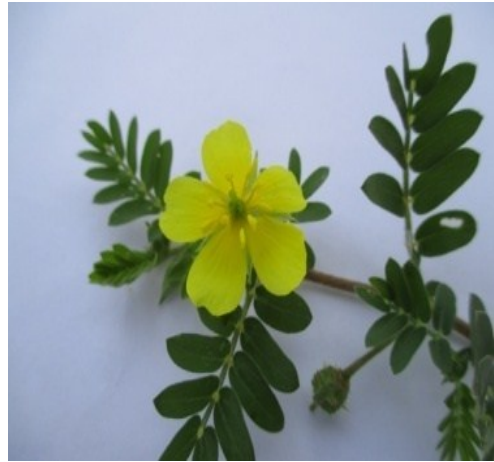

Tribulus terrestris

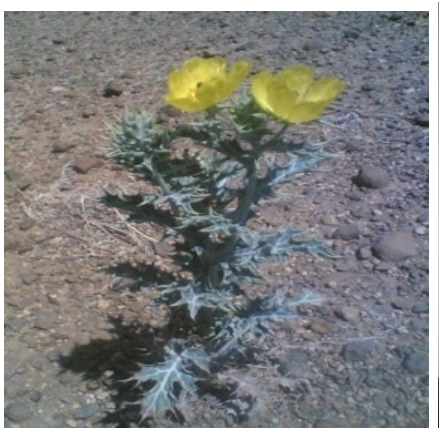

Argemone maxicana

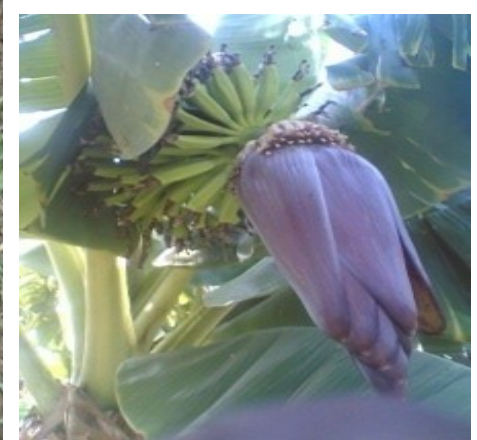

Musa paradisiaca

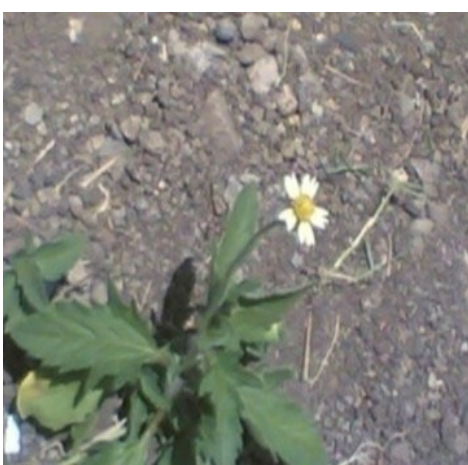

Tridax procumbens

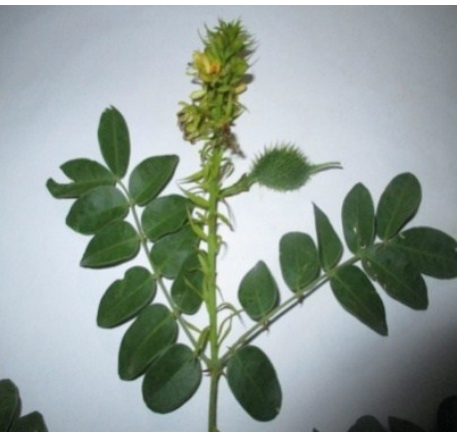

Caesalpinia bunduc

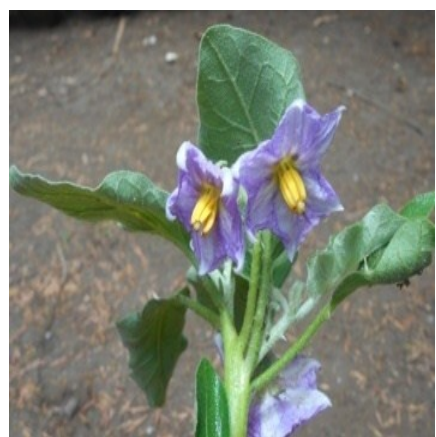

Solanum melongena

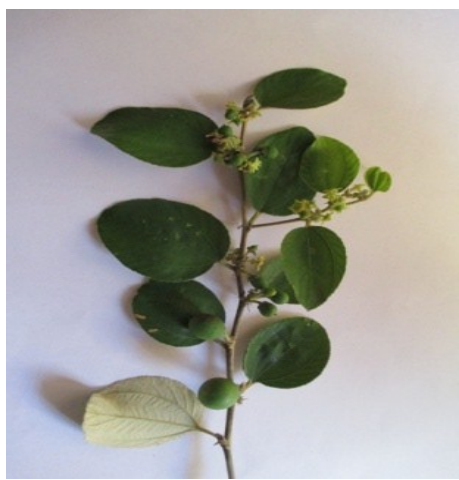

Zizypus mauritiana 
Review of related literature also reveals that medicinal plants used by the traditional practitioners of this area are also recommended on other areas for same purpose (Vasundhara and Bhupati 2007). In Karnataka ethno-botanical studies on medicinal plants were conducted in Chikmagalur (Gopakumar et al 1991), Tumkur (Yoganarasimhan et al 1991), Kodagu (Kalyana Sundaram Indira (1998), Uttar Kannada (Harsha et al 2003), Bidar (Prashantkumar and Vidyasagar 2008), Chitradurga (Hiremath and Taranath. 2010), Shimoga (Rajkumar and Shivanna 2010), Gulbarga (Ghatapanadi 2012) and Bellary (Vidyasagar and murthy siddalinga. 2012) districts. However ethno botanical study on medicinal plants in Vijayapur(Bijapur) district has not been reported. Among the plants reported Caesalpinia bunducella Roxb and Withania somnifera (L.)Dunal. Were the most effective medicinal plants to treat primary infertility in women as prescribed by 12 herbal healers (70\%). Most of the women dependent on traditional herbal medicine because availability of effective drug plants. Hence, these plants can be taken up for further pharmacological and clinical studies.

\section{CONCLUSIONS}

India is a major centre of origin and diversity of medicinal plants. Traditional knowledge of herbal remedy to treat human diseases is fast declining in many parts of the world, including India. In India, about 2500 species belonging to more than 1000 genera and about 158 families are used in indigenous system of medicine.

An ethno-botanical survey of Vijayapur district comprising five tehsils was conducted during February 2014 to December 2015. The main purpose of this survey was to document the traditional use of medicinal plants for primary infertility in women in vijayapur district. 13 species belonging to 13 genera and 12 families were found to be used to treat primary infertility. The scientific name, family, local name, habit along with part used and mode of their administration are provided.

\section{Acknowledgements}

Authors are thankful to traditional practitioners of Vijayapur district, who whole heartedly cooperated in sharing their knowledge and in helping collection of plant material pertaining to the research.

\section{References}

[1] Gamble J.S. and Fischer C.E.C. (1957). Flora of the presidency of Madras, Vol 1-3, BSI, Calcutta

[2] Ghatapanadi S.R, Nicky Johnon and Rajasab A.H.(2012). Documentation of Folk Knowledge on medicinal plants of Gulbarga district,Karnataka,Indian J tradit Knowle, 10(2):349-353

[3] Ghatapanadi S.R., Nicky Johnson and Rajasab A.H.(2010).Medicinal plants of north Karnataka used in treatment of kidney stones and urinary tract infections, The socioscan, Vol 2(3 \&4) pp 2324,2010

[4] Gopakumar K., Vijayalaxmi and Yoganarasimhan S.N. (1991). Plants used in Ayurveda from Chikmagalur district, J Econ Taxon Bot, 15: 379-381. 15. Iyngar Bhat, Bhat K.G., Nayak G.K., Rao Rajgopal and Singh R. (1986). Survey of medicinal flora of South Canara, Indian drugs, 24: 69-73.

[5] Harsha V.H., Hebbar S.S., Sripathi V.and Hegade G. R. (2003). Ethnomedicobotany of Uttar Kannada district of Karnataka, India-Plants used in treatment of skin diseases, J Ethnopharmacol, 84: $37-40$.

[6] Hiremath V.T. and Taranath T.C. (2010). Traditional Phytotherapy for Snake bites by Tribes of Chitradurga District, Karnataka, India, Ethnobot Leaflets, 14: 120-25, 
[7] Kalyana Sundaram Indira. (1998). An Ethnobotanical study of the Kodavas and other tribes of Kodago district, Karnataka, Bull Bot Surv India, 40(1): 47-52.

[8] Khan Nazeerullah, Kumar Sunil, Singh Rishi Pal, Dhankhar Neelam, (2012), A Pharmacognostic and Pharmacological Overview on Caesalpinia bonducella, RJPBCS Volume 3 Issue 1 Page No. 480-496.

[9] Madhu.V. and Ravindra Naik DS (2009).Ethno medicinal Uses of Leaf Preparations in Adilabad District, Andra Pradesh,India. Ethnobotanical Leaflets 13: 1337-47.

[10]Parinitha M., Harish G.U., Vivek N.C., Mahesh T.and Shivanna M.B. (2004). Ethno-botanical wealth of Bhadra wild life sanctuary in Karnataka, Indian J Tradit Knowle, 3(1): 37-50.

[11]Prashantkumar P. and Vidyasagar G.M. (2008). Traditional Knowledge on medicinal plants used for the treatment of skin diseases in Bidar district, Karnataka. Indian J Tradit Knowle, 7 (2): 273276.

[12]Rajash Shukla,Moyna Chakravarty and M.P.Goutham (2008) Indigenous medicine used for treatment of gynaecological disorders by tribal of Chhattisgarh, India. J of Medicinal Plants Research Vol.2(12),pp.356-360.

[13]Rajkumar N. and Shivanna M. B. (2010). Traditional Herbal medicinal Knowledge in Sagar taluk of Shimoga District, Karnataka, India, Indian J Nat Prod Resour, 1(1): 102-108.

[14] Seetharam Y.N., Kotresh k. And Uplaonkar S.B. (2000).Flora of Gulbarga District, Gulbarga Universty, Gulbarga.

[15] Tiwari D.N., Medicinal plants for healthcare, Yojana, 1999, 26(3),8.

[16] Trirathi Rakesh, Dwivedi S.N. and Dwivedi Sumeet (2010).Ethno-medicinal plants used to treat gynecologocal disorders by tribal people of Madhya Pradesh,India,IJPLS,1(3):160-169.

[17] Vasundhara M. And Bhupati vasundhara (2007). Maneyangaladalli oushadhivana, page No. 1318

[18]Vidyasagar G.M. and Murthy Siddalinga S.M. (2012). Ethnomedicinal plants to treat menstrual disorders by tribal people in Bellary district of Karnataka, India, Int. J. Pharm. \& Life Sci.(IJPLS),Vol.3,Issue 7:July:2012,1871-1876

[19] Yoganarasimhan S.N., Togunashi V.S., Keshavmurthy K.R. and Govindaiah. (1991). Medicinal Botany of Tumkur district in Karnataka, India, J Econ and Taxon Bot, 15: 391393. 